\title{
Filamentous fungi isolated from Candeias Beach, Pernambuco, Brazil
}

\author{
Luciana Gonçalves de Oliveira ${ }^{1,3}$, Maria Auxiliadora de Queiroz Cavalcanti ${ }^{1}$, \\ José Zanon de Oliveira Passavante ${ }^{2}$, Maria José dos Santos Fernandes ${ }^{1}$ and Débora Maria de Massa Lima ${ }^{1}$
}

Received: 27.07.2010; accepted: 05.05.2011

\begin{abstract}
Filamentous fungi isolated from Candeias Beach, Pernambuco, Brazil). The main purpose of this study was the isolation and identification of the filamentous mycobiota present on soil and water samples from Candeias Beach, Pernambuco, Brazil. Sampling of soil and water was carried out four times at three randomly chosen spots along the beach, during the rainy and dry seasons, during the low tide. From each soil sample, a suspension was prepared with $50 \mathrm{~g}$ of soil diluted in $90 \mathrm{~mL}$ of sterilized distilled water and $1 \mathrm{~mL}$ was spread in Petri dishes with Sabouraud Agar with Chloramphenicol. Out of each water sample $0,5 \mathrm{~mL}$ was taken and put in sowed triplicate Petri dishes containing Sabouraud Chloramphenicol Agar. A total of 57 species of filamentous fungi are reported, comprising of 19 genera. Aspergillus and Penicillium were the most abundant and diverse genera. Penicillium diversum and Varicosporium elodeae are the first to be recorded in Latin America and Brazilian northeast, respectively.
\end{abstract}

Key words: Aspergillus, marine environment, Penicillium, soil, water

RESUMO - (Fungos filamentosos isolados da praia de Candeias Pernambuco, Brasil). Este trabalho teve como objetivos isolar, identificar fungos filamentosos do solo e da água da praia de Candeias, Jaboatão dos Guararapes, Pernambuco, Brasil. Quatro amostras de solo e água foram coletadas em três pontos aleatórios ao longo da praia, durante os períodos chuvoso e de estiagem, durante a baixa-mar do dia. De cada amostra de solo, foi preparada uma suspensão com $50 \mathrm{~g}$ de solo diluído em $90 \mathrm{~mL}$ de água destilada esterilizada e ao final, $1 \mathrm{~mL}$ foi semeado em placas de Petri contendo Ágar Sabouraud acrescido de cloranfenicol. Da água, $0,5 \mathrm{ml}$ foi semeado em placas de Petri, em triplicatas. Foram identificas 57 espécies correspondentes a 19 gêneros. Aspergillus e Penicillium foram os gêneros mais abundantes. Penicillium diversum e Varicosporium elodeae são novos registros para América Latina e nordeste brasileiro, repectivamente.

Palavras-chave: água, ambiente marinho, Aspergillus, Penicillium, solo

\section{Introduction}

Fungi comprise of a heterogeneous group of heterotrophic microorganisms, which act as saprobes, parasite, and less frequently as symbionts, living in association with other organisms (Dix and Webster 1995). These microorganisms are important components of the environment, feeding on decaying organic matter, being essential for mineral and carbon cycling, both on soil and on water (Hogg \& Hudson 1966, Harley 1971, Triska 1975, Suberkropp \& Klug 1976, Moore- Landecker 1996).
Marine fungi are a general term for a big group of saprobe or parasite fungi found in marine environment (Hyde 1989). Different groups of fungi may be found on water, including the zoosporic fungi, Zygomycetes, Anamorphic fungi, Ascomycetes, and a few Basidiomycetes (Hyde 1997).

According to Sundari et al. (1996), studies on tropical fungi in marine environments have been a matter of great interest in the last decades on the Atlantic, Pacific and Indic Oceans. Among the works published on this subject, the works by Kirk (1983), Udagawa \& Ueda (1985), Tan (1985), Purchio et al.

1. Universidade Federal de Pernambuco, Departamento de Micologia, Av. Prof. Nelson Chaves s/n, Cidade Universitária, 50670-420 Recife, PE, Brazil

2. Universidade Federal de Pernambuco, Centro de Tecnologia e Geociências, Departamento de Oceanografia, Av. Prof. Moraes Rego, 1235, Cidade Universitária, 50670-901 Recife, PE, Brazil

3. Corresponding author: lugoliveira@yahoo.com.br 
(1988), Pinto et al. (1992), Sarquis \& Oliveira (1996), Gomes et al. (2008), Nambiar \& Raveendran (2008), and Dethoup \& Manoch (2009) may be highlighted. On the other hand, Dabrowa et al. (1964), Kishimoto \& Becker (1962), Berger \& Wagner-Merner (1977) reported potential pathogenic fungi from sandy soil beaches.

Compared to the millions of fungal species known for terrestrial environments, only 500 taxa have been reported for oceans and estuaries (Kohlmeyer \& Kohlmeyer 1979, Kohlmeyer \& Volkmann-Kohlmeyer 1991). Recent studies revealed that 3,047 taxa have been reported from aquatic habitats thus far. The largest taxonomic group of fungi in aquatic habitats is comprised of meiosporic and mitosporic Ascomycota, followed by the Chytridiomycota (Shearer et al. 2007).

Mangroves forests are considered as the second most important host for marine fungi. These ecosystems are considered the "hotspots" for marine fungi, there are about 625 species and many factors contribute to their biodiversity, including a wide variety of substrates for fungi, and important environmental gradients (Maria \& Sridhar 2003, Shearer et al. 2007).

Booth (1979) reports the mycota from 43 locations in South America isolated from marine environments, among the fungal groups described are: 50 lignolicolous fungi, 21 foliicolous fungi, 10 rhizosphere fungi, 10 algicolous fungi. The diversity of the aquatic Hyphomycetes in South America was reviewed by Schoenlein-Crusius \& Grandi (2003). The authors published a check-list, totalizing the report of about 90 species of aquatic Hyphomycetes for Argentina, Brazil, Chile, Peru and Venezuela. These authors also make reference to the scarcity of works on this environment.

In Brazil, Pinto et al. (1992), Sarquis \& Oliveira (1996), and Gomes et al. (2008) reported the occurrence and diversity of filamentous diversity of filamentous fungi from from sand and water from Boa Viagem beach (Pernambuco), Ipanema beach (Rio de Janeiro), and Olinda (Pernambuco), respectively.

As the majority of papers dealing with filamentous mycota from marine environments are based on studies in European and North American countries, and just few works have been made in the tropics, the aim of this study was to isolate and identify fungi present in soil and water samples taken from Candeias beach, Jaboatão dos Guararapes, Pernambuco, extending the knowledge on the diversity of fungi in marine environments.

\section{Material and methods}

Study area - The city of Jaboatão dos Guararapes has a total of $234 \mathrm{~km}^{2}$, corresponding to $10.64 \%$ of the metropolitan region of Recife. It is drained by Capibaribe, Pirapama and Jaboatão rivers. Jaboatão river receives organic pollution from sugar mills located near its basins, as well as sewage from nearby cities, villages and industrial centers. Candeias beach is located between the parallels $8^{\circ} 13^{\prime} 29^{\prime \prime} \mathrm{S}-34^{\circ} 55^{\prime} 60^{\prime \prime} \mathrm{W}$ south latitude and is about $4.2 \mathrm{~km}$ long. Its littoral is characterized for not emerging reefs during low-tide, exposing the shore to direct impact of waves. In its infralittoral is a line of reefs, composed of dead seaweed that emerges during extremely low tides (CoelhoSantos 1993, CPRH 1995).

Sampling procedure - Soil samples were collected in three randomly chosen spots along the shore, at $20 \mathrm{~cm}$ deep, during the dry and rainy seasons, in the months of January and February/2004, and June and July/2004. Soil samples were taken with a garden shovel, and put into plastic bags. Water samples were collected from $1 \mathrm{~m}$ deep, in three randomly chosen spots in the sea, using sterilized and labeled test tubes. These samples were taken in the same period as the soil samples. Abiotic paraments such as $\mathrm{pH}$, temperature, water and soil salinity were also measured. The samples were brought to the laboratory of the Mycology Department of the Federal University of Pernambuco, for appropriate analysis.

Out of each soil sample, an aqueous suspension was made with $50 \mathrm{~g}$ of soil for $90 \mathrm{~mL}$ of distilled sterilized water (Clark 1965, modified), $1 \mathrm{~mL}$ of this suspension was sown in Petri-dishes, in triplicate, containing Sabouraud-chloramphenicol agar. Out of each water sample, $0.5 \mathrm{~mL}$ was taken and sown in Petri-dishes containing Sabouraud-chloramphenicol agar. The dishes were kept at $28{ }^{\circ} \mathrm{C}\left( \pm 2{ }^{\circ} \mathrm{C}\right)$, and with the development of the first colonies, they were seeded in test tubes containing Sabouraud Agar.

In order to purify the fungi samples, colonies fragments were transferred to Petri-dishes containing Sabouraud-chloramphenicol agar; after purity confirmation, fragments were seeded in Potato Dextrose Agar, Malt Agar or Czapek, placed in test tubes.

For identification, macroscopical (color, colonies diameter and aspects of colonies) and microscopical characters (microstructures) were observed according to Ellis (1971, 1976), Rapper and Fennell (1977), 
Carmichael et al. (1980), Sutton (1980), Pitt (1988), Domsch et al. (2007), among others. The slide culture technique was used when needed according to Ridell (1950).

Statistical analysis - Aiming to compare the influence of seasonality on the occurrence of filamentous fungi isolated from soil and water samples, the Analysis of Variance (ANOVA) with two factors was carried out with Stat Software.

\section{Results and Discussion}

From the four soils and water samples carried out in Candeias beach during the dry and rainy seasons 57 species of filamentous fungi were identified. The majority belong to the anamorphic fungi with 52 species, followed by Ascomycota and Zygomycota with three and two species respectively (table 1). These results are in agreement with works on fungi in marine environments carried out in California, Hawaii, Florida, Boa Viagem and Olinda (Pernambuco, Brazil), Rio de Janeiro (Brazil) (Dabrowa et al. 1964, Kishimoto \& Baker 1969, Bergen \& Wagner-Merner 1977, Pinto et al. 1992, Sarquis \& Oliveira 1996, Gomes et al. 2008).

Among the genera isolated from soil samples, 36 species are recorded: Penicillium sp. (10), Aspergillus sp. (8), Phoma sp. (4), Trichoderma sp. (3), Microsphaeropsis sp. (2), Absidia sp. (1), Cladosporium sp. (1), Fusarium sp. (1), Malbranchea sp. (1), Pestalotiopsis sp. (1), Syncephalastrum sp. (1), Talaromyces sp. (1), Thielavia sp. (1) and Varicosporium sp. (1). The fungi isolated from water showed similar results related the number of species (33): Penicillium sp. (12), Aspergillus sp. (6), Cladosporium sp. (2), Trichoderma sp. (2), Phoma sp. (2), and Acremonium sp. (1), Chaetomium sp. (1), Curvularia sp. (1), Fusarium sp. (1), Malbranchea sp. (1), , Myrothecium sp. (1), Phomopsis sp. (1), Syncephalastrum sp. (1), and non-sporulating fungi (1). These data are coincident with those reported by Larrondo \& Calvo (1989), Sarquis \& Oliveira (1996) who mentioned the constant presence of Penicillium and Aspergillus in the mycoflora in sands of Mediterranean coast and Ipanema beaches.

A total of 204 colony forming units (CFU) were obtained, and they were represented specially by Penicillium commune Thom (71), Aspergillus niger Tiegh.(18), A. janus Raper \& Thom (11), A. sydowii (Bainier \& Sartory) Thom \& Church (1926) (8), and
Trichoderma virens (J.H. Mill., Giddens \& A.A. Foster) Arx (6).

Results of the statistical analysis show no significant difference between fungi isolated from soil and fungi isolated from water $(\mathrm{DF}=8 ; \mathrm{p}=0.1703)$, as well as no significant difference between fungi isolated from water and from soil related to seasonality (rainy and dry season) $(\mathrm{DF}=8 ; \mathrm{p}=0.5943)$. Ananda $\&$ Sridhar (2004) observed different results in mangrove forests, in the southwest coast of India, revealing significant difference in the frequency of occurrence of fungal taxa during different incubation periods of leaf litter as well as woody litter. However, Maria \& Sridhar (2003) reported no difference was found in the percentage frequency of occurrence of fungi in different hosts on Mangrove forests during the seasons.

Out of the 57 isolated and identified species, 30 of them have been already reported by Pinto et al. (1992) for Boa Viagem beach: Acremonium bacillisporium, Aspergillus carbonarius, A. flavipes, A. flavus, A. fumigatus, A. niger, A. sydowii, A. terreus, Cladosporium cladosporioides, C. sphaerospermum, C. tenuissimum, Fusarium solani, Malbranchea gypsea, Microsphaeropsis olivaceae, Myrothecium roridum, Penicillium brevicompactum, P. commune, $P$. corylophilum, $P$. glabrum, $P$. implicatum, P. islandicum, P. lividum, P.restrictum, P. waksmanii, Pestalotipsis guepini, Phoma capitulum, Phoma tropica, Syncephlastrum racemosumm, Trichoderma harzianum and T. pseudokoningii. Bergen \& WagnerMerner (1977) isolated and identified 30 species in Florida, of which only Aspergillus fumigatus, A. niger, and Fusarium solani occurred in the present research. Sarquis \& Oliveira (1996) reported the occurrence of 170 species of fungi in Ipanema beach (Rio de Janeiro), of which Aspergillus flavus, A. fumigatus, A. niger, A. parasiticus, A. sulphureus, A. sydowii, A. terreus, Cladosporium cladosporioides, C. sphaerospermum, Fusarium nivale, F. solani, Penicillium canescens, P. corylophilum, P. citrinum, P. crustosum, P. fellutanum, P. glabrum, $P$. griseofulvum, P. implicatum, P. lividum, P. purpurogenum, P. waksmanii, Trichoderma harzianum, T. koningii, and T. pseudokoningii were also observed in Candeias beach.

Out of the identified taxa, Varicosporium elodeae and Penicillium diversum have been cited as first records for Brazilian Northeast and South America respectively, as isolated from marine environment. 
Table 1. Colony forming units (CFU) of isolated fungi from water and soil samples collected at Candeias beach. I; II; III = collecting sites; $\mathrm{C}=$ rainy season; $\mathrm{E}=$ dry season.



\section{ASCOMYCOTA \\ Chaetomium dolichotrichum L.M. Ames}

Talaromyces wortmanii (Klöcker) C.R. Benj.

Thielavia minor (Rayss \& Borut) Malloch \& Cain

ANAMORPHIC FUNGI

Acremonium bacillisporium(Onions \& G.L.Barron) W.Gams 2

Aspergillus carbonarius (Bainier) Thom

A. flavipes (Bainier \& R. Sartory) Thom \& Church

A. flavus Link

A. fumigatus Fresen.

A. janus Raper \& Thom

A. niger Tiegh.

A. parasiticus Speare

A. sulphureus (Fresen.) Thom \& Church

A. terreus Thom

Cladosporium cladosporioides (Fresen.) G. A. de Vries

C. sphaerospermum Penz.

C. tenuissimum Cooke

Curvularia eragrostidis (Henn.) J.A. Meyer

Fusarium nivale (Fr.) Sorauer

F. solani (Mart.) App. \& Sacc.

Malbranchea gypsea Singler \& J.W. Carmich.

Microsphaeropsis arundinis (S. Ahmad) B. Sutton

M. olivaceae (Bonord.) Höhn.

Myrothecium roridum Tode ex Fr.

Penicillim brevicompactum Dierckx

P. canescens Sopp

P. citrinum Thom

P. corylophilum Dierckx

P. commune Thom

$P$. diversum Raper \& Fennell

P. fellutanum Biourge

P. funiculosum Thom

P. glabrum (Wehmer) Westling

$P$. griseofulvum Dierckx

$P$. herquei Bainier \& Sartory

P. implicatum Biourge

P. islandicum Sopp

P. lividum Westling

P. purpurogenum Stoll

P. simplicissimum (Oudem.) Thom

$P$. solitum Westling

P. waksmanii Z.M. Zaleski

Pestalotiopsis guepini (Desm.) Steyaert

Phoma capitulum Pawar, P.N. Mathur \& Thirum.

P. leveillei Boerema \& G.J. Bollew

P. lingam (Tode ) Desm.

P. sorghina (Sacc.) Boerema, Dorenb. \& Kesteren

P. tropica R. Schneid. \& Boerema

Phomopsis archeri B. Sutton

Trichoderma harzianum Rifai

$\begin{array}{llllllllllllll}- & - & - & 1 & - & - & - & - & - & - & - & - & 1 \\ - & - & - & - & - & - & 1 & - & - & - & - & - & 1 \\ - & - & - & - & - & - & - & - & 1 & - & - & - & 1\end{array}$




\begin{tabular}{|c|c|c|c|c|c|c|c|c|c|c|c|c|c|}
\hline \multirow[t]{3}{*}{ Genera/Species } & \multicolumn{6}{|c|}{ Water } & \multicolumn{6}{|c|}{ Soil } & \multirow{3}{*}{$\begin{array}{c}\text { Total of } \\
\text { CFU }\end{array}$} \\
\hline & \multicolumn{2}{|c|}{ I } & \multicolumn{2}{|c|}{ II } & \multicolumn{2}{|c|}{ III } & \multicolumn{2}{|c|}{$\mathrm{I}$} & \multicolumn{2}{|c|}{ II } & \multicolumn{2}{|c|}{ III } & \\
\hline & $\mathrm{C}$ & $\mathrm{E}$ & $\mathrm{C}$ & $\mathrm{E}$ & $\mathrm{C}$ & $\mathrm{E}$ & $\mathrm{C}$ & $\mathrm{E}$ & $\mathrm{C}$ & $\mathrm{E}$ & $\mathrm{C}$ & $\mathrm{E}$ & \\
\hline T. koningii Oudem. & - & - & - & - & - & - & - & - & 1 & - & - & - & 1 \\
\hline T. pseudokoningii Rifai & - & - & 1 & - & - & - & - & - & - & - & - & - & 1 \\
\hline T. virens (J.H. Mill., Giddens \& A.A. Foster) Arx & - & - & - & - & - & 2 & - & - & 2 & - & 1 & 1 & 6 \\
\hline Varicosporium elodeae W. Kegel & - & - & - & - & - & - & 1 & - & - & - & - & - & 1 \\
\hline Syncephalastrum racemosum Cohn ex J. Schrot. & - & - & - & - & - & 2 & - & - & - & 1 & - & - & 3 \\
\hline No esporulated fungi & - & 2 & - & - & - & - & - & - & - & - & - & - & 2 \\
\hline Total of CFU & & & & & & & & & & & & & 204 \\
\hline
\end{tabular}

Varicosporium elodeae had been previously reported as being isolated from decaying leaves of Oje in Río Motanti, Peru (Matsushima 1993), and SchoenleinCrusius et al. (2009) reported this specie from leaf litter in São Paulo (Brazil). Penicillium diversum was first isolated from leather objects in Europe (Raper 1977).

From the water samples, only two samples of non-sporulating fungi were isolated. Hyaline and dark mycelia that do not present sporulation after alternate passage trough different media were considered to be non-sporulatting. Sarquis \& Oliveira (1996) observed a lower incidence of non-sporulating fungi in Ipanema beach (Rio de Janeiro). For other land, studies carried out by Purchio et al. (1988) considered non-sporulatting fungi as an indicator of microbial pollution of sea and river waters.

The study of fungi in marine environment is based on the knowledge that coastal waters suffer the environmental effects of coastal lands (Purchio et al. 1988).According to Bergen \& Wagner-Merner (1977), many factors can influence the fungal development and diversity such as the number of bathers, the temperature, and the difference in salinity. Larrondo \& Calvo (1989) suggested that rain, the force of gravity, turbulence and relative humidity are the main environmental conditions which can influence in the presence of viable conidia. Pinto et al. (1992) suggested that the foam play a role in the dispersion in estuaries and terrestrial environments. Thus, works in this environment are on the increase to enhance knowledge on microfungi biodiversity.

\section{Acknowledgments}

The work was enabled by Masters Fellowship that was awarded to the first author from the "Conselho
Nacional de Desenvolvimento Científico e Tecnológico" (CNPq). The authors are grateful to Dr. Nelson Onyango for English text revision.

\section{Literature cited}

Ananda, K. \& Sridhar, K.R. 2004. Diversity of filamentous fungi on decomposing leaf and woody litter of mangrove forests in the southwest coast of India. Current Science 87: 1431-1437.

Bergen, L. \& Wagner-Merner, D.T. 1977. Comparative survey of fungi and potential pathogenic fungi from selected beaches in the Tampa Bay area. Mycologia 69:299-308.

Booth, T. 1979. Strategies for study of fungi marine and marine influenced ecosystems. Revista de Microbiologia 10: 123-138.

Carmichael, J.W., Kendrick, W.B., Conners, I.L. \& Singler, L. 1980. Genera of Hyphomycetes. University of Alberta Press, Alberta.

Clark, F.E. 1965. Agar-plate method for total microbial count. In: C.A Black, D.D Evans, J.L. White, L.E. Ensminger, F.E. Clark \& R.C. Dinaver (eds.). Methods of soil analysis. chemical and microbiological properties. Madson, New York, part 2, pp. 1460- 1466.

CPRH. 1999. Relatório da Bacia hidrográfica dos Rios Pirapama e Jaboatão, Recife. Companhia Pernambucana de Controle da Poluição Ambiental e de Administração dos Recursos Hídricos, Recife.

Coelho-Santos, M.A. 1993. Crustáceos decápodos do Litoral de Jaboatão dos Guararapes, PE (BR), Dissertação de Mestrado, Departamento de Oceonografia da Universidade Federal de Pernambuco, Recife.

Dabrowa, N., Landan, J.W., Newcomer, V.D. \& Plunkett, O.A. 1964. A survey of tide-washed coastal area of Southern California for fungi potentially pathogenic to man. Mycopathologia et Mycologia Applicata 24: 137-150. 
Dethoup, T. \& Manoch, L. 2009. Diversity of Marine Fungi in Eastern Thailand. Kasetsart Journal, (Natural Sciences) 43: 100-106.

Dix, N.I. \& Webster, J. 1995. Fungal Ecology. Cambridge University, London.

Domsch, K.H., Gams, W. \& Anderson, T.H. 2007. Compendium of soil fungi. IHW- Verlag, San Francisco.

Ellis, M.B. 1976. More Dematiaceous Hyphomycetes. Commonwealth Mycological Institute, Kew.

Ellis, M.B. 1971. Dematiaceous Hyphomycetes. Commonwealth Mycological Institute, Kew.

Gomes, D.N.F., Cavalcanti, M.A.Q., Fernandes, M.J.S., Lima, D.M.M. \& Passavante, J.Z.O. 2008. Filamentous fungi isolated from sand and water of "Bairro Novo" and "Casa Caiada" beaches, Olinda, Pernambuco, Brazil. Brazilian Journal of Biology 68: 577-582.

Harley, J.L. 1971. Fungi in Ecosystems. Journal of Ecology 59: 34-49.

Hogg, B.M. \& Hudson, H.J. 1966. Microfungi on leaves of Fagus sylvatica. The microfungal sucessions. Transaction of the British Mycological Society 49: 185-192.

Hyde, K.D. 1989. Ecology of tropical marine fungi. Hydrobiologia 178: 199-208.

Hyde, K.D. 1997. Biodiversity of tropical microfungi. Hong Kong University Press, Hong Kong.

Kirk, P.W.J.R. 1983. Direct enumeration of marine arenicolous fungi. Mycologia 75: 670-682.

Kishimoto, R.A. \& Baker, G.F. 1969. Pathogenic and potencially pathogenic fungi isolated from beach sands and selected soils of Oahu, Hawai. Mycologia 61: 537-548.

Kohlmeyer, J. \& Volkmann-Kohlmeyer, B. 1991. Ilustrated key to the filamentous higher marine fungi. Botanica Marina 34: 1-61.

Kohlmeyer, J. \& Kohlmeyer, E. 1979. Marine Ecology: The higher fungi. Academic Press, London.

Larrondo, J.V. \& Calvo, M.A. 1989. Fungal diversity in the sands of the Mediterranean coast beaches Mycopathologia 108: 185-193.

Maria, G.L. \& Sridhar, K.R. 2003. Diversity of filamentous fungi on woody litter of five mangrove plant species from the southwest coast of India. Fungal Diversity 14: 109-126.

Matsushima, T. 1993. Matsushima Mycological Memoirs 7:75p.

Moore-Landecker, E. 1996. Fundamentals of the fungi. Pentice-Hall, New Jersey.

Nambiar, G.R. \& Raveendran, K. 2008.AChecklist of Marine Fungi from Kerala State, India. American-Eurasian Journal of Botany 1: 73-77.
Pinto, I.M.A., Cavalcanti, M.A.Q. \& Passavante, J.Z.O. 1992. Hongos filamentosos aislados del suelo y el agua en la playa de Boa Viagem (Recife-PE, Brasil). Boletín Micológico 7: 39-45.

Pitt, J.I.A. 1988. A laboratory guide to commons Penicillium species. Commonwealth., North Ryde.

Purchio, A., Gambale, W. \& Paula, C.R. 1988. Molds from some beaches in the southern area of São Paulo state (Baixada Santista), Brazil. Revista de Microbiologia 19: 166-171.

Raper, K.B. \& Fenell, D.I. 1977. The genus Aspergillus. Robert and Krieger, Malabar.

Riddell, R.W. 1950. Permanent stained mycological preparation obtained by slide culture. Mycologia 42: 265-270.

Sarquis, M.I.M. \& Oliveira, P.C. 1996. Diversity of microfungi in the sandy soil of Ipanema Beach, Rio de Janeiro, Brazil. Journal of Basic Microbiology 36: 51-58.

Schoenlein-Crusius, I.H. \& Grandi, R.A.I.P. 2003. The diversity of aquatic Hyphomycetes in South America, Brazilian Journal of Microbiology 34: 183-193.

Schoenlein-Crusius, I.H., Moreira, C.G. \& Bicudo, D.C. 2009. Aquatic Hyphomycetes in the Parque Estadual das Fontes do Ipiranga - PEFI, São Paulo, Brazil. Revista Brasileira de Botânica 32: 411- 426.

Shearer, C.A., Descals, E., Kohlmeyer, B., Kohlmeyer, J., Marvanová, L., Padgett, D., Porter, D., Raja, H.A., Schmit, J.P., Thorton, H.A. \& Voglymayr, H. 2007. Fungal biodiversity in aquatic habitats. Biodiversity and Conservation 16: 49-67.

Suberkropp, K. \& Klug, M.J. 1976. Fungi and bacteria associated with leaves during processing in a woodland stream. Ecology 57: 707-719.

Sundari, R., Vikneswary, S., Yusoff, M. \& Jones, E.B.G. 1996. Observations on tropical arenicolous marine fungi on driftwood from Malaysia and Singapore. Botanica Marina 39: 327-333.

Sutton, B.C. 1980. The Coelomycetes: fungi imperfect with picnidia, acervuli, and stroma. CAAB International Mycological Institute, Kew.

Tan, T.K. 1985. Observations on marine fungi in Singapore and Penang (Malaysia). Transaction of the British Mycological Society 85: 726-727.

Triska, K.J., Sedell, J.R. \& Buckley, B. 1975. The processing of conif and hardwood leaves in two coniferous forest streams: II Biochemical and nutrient changes. Vereinigung für Theoretische und Angrwanten Limnologue 19: 1628-1639.

Udagawa, A.S. \& Ueda, S. 1985. Anew species of Podospora from marine sediment. Mycotaxon 22: 399-406. 